\title{
Assessment of Timber Resource Exploitation in Shasha Forest Reserve, Osun State, Nigeria: Implication for Sustainable Forestry
}

\section{${ }^{1}$ OLAJIIRE-AJAYI, BL; ${ }^{1}$ ADENUGA, DA; ${ }^{2}$ OLATUNJI, BT ; ${ }^{3}$ ABEGUNRIN, OO; ${ }^{3}$ ADEBAYO, AS; ${ }^{4}$ ADEDIPE, JO}

\author{
${ }^{*}$ Forestry Technology Department, Federal College of Forestry, Ibadan, Nigeria \\ ${ }^{2}$ Department of Forest Economics and Extension, Forestry Research Institute of Nigeria \\ ${ }^{3}$ Department of Agricultural Extension and Management, Federal College of Forestry, Ibadan, Nigeria \\ ${ }^{4}$ Department of Agricultural technology, Federal College of Forestry, Ibadan \\ *Corresponding Author Email: jiirebolanle@gmail.com; Tel: 08030785074
}

\begin{abstract}
Records on rate of timber exploitation are very essential for sustainable forestry. They help in managing the forest sustainably. Therefore, the study collected and analysed data on rate of timber exploitation in Shasha forest reserve in Osun state. Logs arranged and set to be taken out of the forest were identified and measured every Monday between December, 2017 and June, 2018 for twenty-eight (28) weeks. The species and families of logs encountered were identified. A total of 13,944 logs were assessed. Fifteen (15) families belonging to twenty-one (21) species of logs were identified. Result revealed that Sterculiaceae family with five species was the most exploited. Ricinodendron heudelotti has the highest number of exploited logs with overall frequency of $27.71 \%$. Ricinodendron heudelotti had the highest basal area and volume with values of $18018776.71 \mathrm{~cm}^{2}$ and $113289.36 \mathrm{~cm}^{3}$ respectively. The study concludes that the population of Ricinodendron heudelotii tree was high in Shasha forest which made it available for extraction at high rate. The study recommends strict monitoring and enforcement of sustainable forestry laws with regular inventory and up-to-date inventory of timber exploitation rate from the reserve.
\end{abstract}

\section{DOI: https://dx.doi.org/10.4314/jasem.v25i8.3}

Copyright: Copyright $\left({ }^{\circ} 2021\right.$ Olajiire-Ajayi et al. This is an open access article distributed under the Creative Commons Attribution License (CCL), which permits unrestricted use, distribution, and reproduction in any medium, provided the original work is properly cited.

Dates: Received: 10 May 2021; Revised: 28 June 2021; Accepted: 01 July 2021

Keywords: Exploitation, Deforestation, Forest reserve, Sustainable forestry

Exploitation of forest resources often causes deforestation (permanent destruction of indigenous forests or woodlands). According to International Institute of Tropical Agriculture (IITA), Nigeria has lost about 400,000 hectares of forest land to deforestation. It was reported that huge sum of 180 billion naira is loss annually to deforestation. Exploitation has both positive and negative implications. Among the positive implications are its contribution to income, its associated reduction of poverty, creation of employment and a huge contribution to both national and local economies. On the other hand, the negative implications include; depletion of the resource base, erosion, contribution climate change and extinction of indigenous forest species (Iheke and Eziuche, 2016). Forest resources exploitation is a precondition for livelihood of forested communities, who do not have alternative sources of income (Chilalo and Wiersum, 2011). Forest management is plagued with multiple challenges as guiding rules of managing forest in a sustainable way are longer in operation (Adekunle et al., 2010). In Nigeria today, forest management is faced with challenges such as illegal felling, over exploitation, deforestation/ and or conversion to other land use to mention a few due to population expansion and its attendant anthropogenic activities. These constitute serious threat to sustainable forestry. Sustainable forestry is defined as the system of managing the forest to meet the current needs and desires of the society for forest resources, without undermining the availability of these resources to upcoming generation (Boyle et al., 2016). That is, reduce the pace of forest destruction, while meeting the needs of the present generation without compromising the need of future generation. The indicator of sustainable forestry is a forestry practice that imitates natural pattern of disturbance and regeneration. Thus, helping to maintain a balance the environment, wildlife. Several studies have shown that timber components have been widely acknowledged as a great contributor to both national and local economies (Iheke and Eziuche, 2016), not many of such studies have captured the rate of exploitation in terms of quantity. Forests are fragmenting, shrinking, and getting deforested. Most of the forest areas are drifting towards lower limits of resiliency (FAO, 2000). This is evident in Shasha forest reserve. Also, despite the immense value of this 
timber resource, forests within Shasha forest reserve are been cleared as demand for timber increases. The extreme exploitation of timber resources has reduced their range and abundance compared with what was obtainable in the past. Record keeping system is very poor in Nigeria (Adekunle et al., 2010). Consequently, data on rate of timber exploitation are generally lacking for reserves across Nigeria. If available, analysis and comparism will be easy. This will make for informed decision and effective management planning on sustainable utilization of these resources. Therefore, needs for research on the rate at which timber are exploited from our reserves. This study therefore seeks to assess the timber resource exploitation within Shasha forest reserve, Osun State, Nigeria. Specifically, to ascertain the rate of exploitation during the current harvesting period, identify the various species exploited and also determine the volume of logs (portion of trees which had been cut to different sizes depending upon taper or the need of length) exploited. This study will help in the sustainable conservation and effective management of the Shasha forest reserve.

\section{MATERIALS AND METHODS}

Study Area: The research was carried out in Shasha Forest Reserve, Osun State, Nigeria. The forest is situated between latitude $6^{\circ} 5^{\prime} 0 \mathrm{~N}$ to $7^{\circ} 80^{\prime} \mathrm{N}$ and longitude $40^{\circ} 10^{\prime} \mathrm{E}$ to $4^{\circ} 45^{\prime} \mathrm{E}$. It occupies a total land area of $31,541 \mathrm{Ha}$. The reserve was first gazette in
1925 as part of the old Shasha Forest Reserve under an agreement with the Ijebu Native Authority. The reserve shares boundaries with Omo Forest Reserve on the west. The northern and eastern boundaries are with Ife Forest Reserve and Oluwa Forest Reserve in Osun state and Ondo state respectively. The reserve is subdivided into two major Areas; 4 and 5. There are about forty communities within and around the forest reserve. The population of these communities range from 200 to 2000 inhabitants (Olokeogun et al., 2014). Shasha Forest Reserve is in the lowland rain forest of South- Western Nigeria. The annual rainfall ranges from $890 \mathrm{~mm}$ to $2200 \mathrm{~mm}$. The rainy season in Shasha Forest Reserve commences from March/April and lasts till November. The average relative humidity is $70 \%$ while the mean monthly temperature is $28^{\circ} \mathrm{C}$. There are two main seasons in the year, a dry season with dry northeast trade wind which causes Harmattan predominates from November to March, and a rainy season characterized by the South-west monsoon wind which brings rain from April to October(Olokeogun et al ., 2014). The topography of the area is generally undulating, lying at altitude between $90 \mathrm{~m}$ and $140 \mathrm{~m}$ above sea level. The vegetation is mainly a high forest type. The soil of the area were formed from rocks of Pre-Cambrian basement complex formation particularly granites, gneisses, quartz-schist, biotite gneisses and schist. They were formed under moist semi-deciduous forest cover and belong to the major soil group called ferruginous tropical soil (Olokeogun et al., 2014).

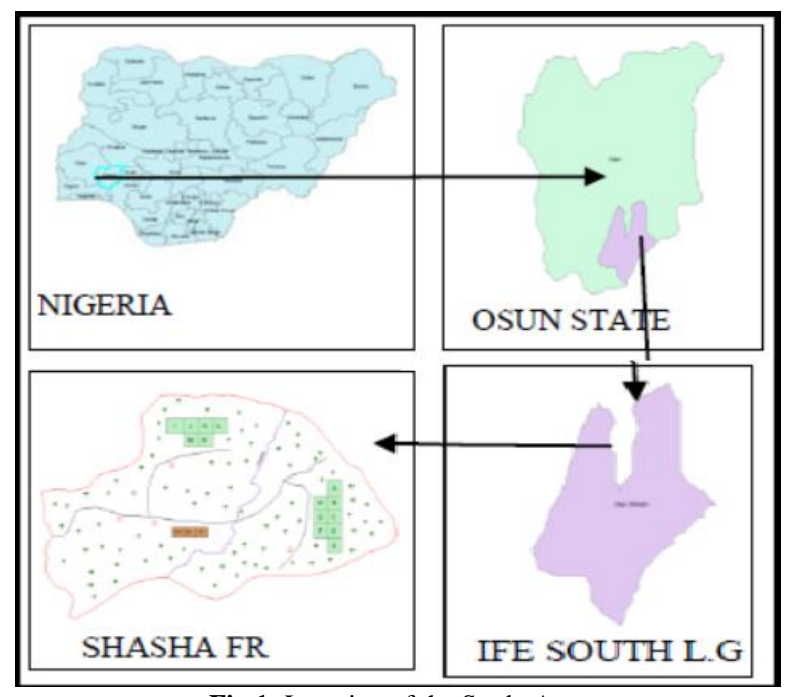

Fig 1: Location of the Study Area

Data Collection: The logs arranged and set to be taken out of the forest were identified and measured every Monday between December, 2017 and June, 2018 for twenty-eight (28) weeks. The species and families of logs encountered were identified using the identification guide manual of trees of Nigeria (Keay, 1989) and with the assistance of a taxonomist at Forest Herbarium, Ibadan (FHI).The log length was measured using a measuring tape while the diameter at both end points of $\log$ and diameter at middle of the 
log were measured using girthing tape. A total number of 13,944 logs were assessed.

Data analysis: The data collected from the measurements were analysed using the following methods;

Basal Area (BA)

$$
B A=\frac{\pi d^{2}}{4}
$$

Where; $\mathrm{BA}=$ Basal area $\left(\mathrm{m}^{2}\right) ; \boldsymbol{\pi}=3.14 ; \mathrm{d}=$ Diameter

Volume Estimation: Volume was estimated from basal area of $\operatorname{logs}$ (at both end points of the log and middle of the $\log$ ) and $\log$ length. Based on the data collection from this study, the volume was estimated using Newton's formula (Husch et al., 2003).

$$
V=\frac{S_{1}+4 S_{m}+S_{2} \times 1}{6}
$$

Where; $S_{1}, S_{2}=B A$ at end points of log: $4 S_{m}=B A$ at middle of the $\log ; 1=$ length of $\log ; \mathrm{V}=$ Volume

\section{RESULTS AND DISCUSSION}

Species Composition of Logs: Table 1 shows name, family and the number of the species that are exploited between the study periods. It was observed that fifteen (15) families belonging to twenty-one (21) species of logs were exploited during the study period. Sterculiaceae family has the highest number of species with five (5) species, followed by Combretaceae and Fabaceae families with two (2) species while other families has a single species each. Also Ricinodendron heudelotii of Euphorbiaceae family has the highest number of exploited logs with $27.71 \%$, followed by Irvingia gabonensis with $12.05 \%$ while Brachystegia nigerica and Mansonia altissima had the least percentage frequency of $0.60 \%$.

Basal Area: Figure 2 show that Ricinodendron dronheudelotii has the highest basal area of $18018776.71 \mathrm{~cm}^{2}, 24215571.63 \mathrm{~cm}^{2}$ and 30113289.36 $\mathrm{cm}^{2}$ at top, middle and at the base respectively. This is closely followed by Irvingia gabonensis with $2772657.95 \mathrm{~cm}^{2}, 4125835.93 \mathrm{~cm}^{2}$ and $5278630.22 \mathrm{~cm}^{2}$ for top, middle and Diameter at Breast Height respectively and Terminalia Ivorensis with basal area of $1878337.01 \mathrm{~cm}^{2}, 2345804.45 \mathrm{~cm}^{2}$ and 2925130.27 $\mathrm{cm}^{2}$ for top, middle and base respectively while Mansonia altissima has the least basal area of 6789.80 $\mathrm{cm}^{2}$ at the top, $7331.94 \mathrm{~cm}^{2}$ at the middle and 8570.35 $\mathrm{cm}^{2}$ at the base.

Volume Estimation: Figure 2 show that the Ricinodendron heudelotii has the highest volume of $88398223.62 \mathrm{~cm}^{3}$ which followed by Irvingia gabonensis and Terminalia ivorensis with estimate volume of $14970140.57 \mathrm{~cm}^{3}$ and $8649149.00 \mathrm{~cm}^{3}$ respectively while Mansonia altissima has the least volume of $27244.73 \mathrm{~cm}^{3}$

Table 1: Species Composition of logs

\begin{tabular}{lllll}
\hline S/N & Family & Species & Frequency & \% Frequency \\
\hline 1 & Apocynaceae & Alstoniaboonei & 252 & 1.81 \\
2 & Boraginaceae & Cordiamillenii & 336 & 2.41 \\
3 & Combretaceae & Terminalia superba & 336 & 2.41 \\
& & Terminalia ivorensis & 1232 & 8.84 \\
4 & Cucurbitaceae & Cucurbita klaineana & 924 & 6.63 \\
5 & Dilleniaceae & Tetracera potatoria & 84 & 0.60 \\
6 & Ebenaceae & Diospyros iturensis & 504 & 3.61 \\
7 & Euphorbiaceae & Ricinodendron heudelotii & 3864 & 27.71 \\
8 & Fabaceae & Albizia lebbeck & 420 & 3.01 \\
& & Millettia thonningii & 560 & 4.02 \\
9 & Irvingiaceae & Irvingia gabonensis & 1680 & 12.05 \\
10 & Leguminosae & Brachystegia nigerica & 84 & 0.60 \\
11 & Malvaceae & Ceiba pentandra & 504 & 3.61 \\
12 & Moraceae & Ficus exasperate & 812 & 5.82 \\
13 & Sapotaceae & Chrysophyllum albidum & 168 & 1.20 \\
14 & Sterculiaceae & Cola gigantean & 224 & 1.61 \\
& & Mansonia altissima & 84 & 0.60 \\
& & Nesogordonia papaverifera & 868 & 6.22 \\
& & Sterculia oblonga & 252 & 1.81 \\
& & Triplochiton scleroxylon & 532 & 3.82 \\
15 & Ulmaceae & Celtis zenkeri & 224 & 1.61 \\
Total & & & $\mathbf{1 3 9 4 4}$ & \\
\hline
\end{tabular}

Fuwape, (2001) and Adekunle et al. (2010) assert that timber exploitation if not well planned could be detrimental to the environment and biodiversity conservation. The result from the study revealed a high rate of timber exploitation. This is against the tenets of sustainable forestry (Adekunle et al., 2010) and will in the long run results in overharvesting and in some cases complete extinction of some indigenous species. Ricinodendron heudelotii reported as one of the highest species by Adekunle (2006) in Shasha are now 
been harvested. This might be due to rapid growth rate, level of maturity and market demand. The volume of trees exploited from the reserve is very high. This is an indication that the demand for timber is higher than what can be sustainably supplied. From the study, 13,944 timbers were extracted without replacement (reforestation) which can cause the extinction of some species in the particular forest reserve which is in accordance with the findings of Field Trip Earth in 2008. This agrees with the study of Olajide et al. (2008) who reported that what is removed from the reserves are more than the natural regenerative ability of the forest and subsequently its resilience. This can further result in the massive clearing of the forest reserve inherent exposure of the soil surface thereby increasing local evapotranspiration. This in turn can possibly cause imminent and complete loss of the forest reserve via unsustainable logging and obvious alteration of the microclimate of the environment. The continuous harvesting of timber without adequate plan to replenish will lead to forest that are degraded both genetically and systematically. This affects the forest ability to perform its multifunctional ecosystem services (Gamfeldt et al., 2013; Ratcliffe et al., 2017). Therefore, a clarion calls to rethink and earnestly bring to play the tenets of sustainable forest management which is the way out of the total collapse of our forests. Sustainable forestry avails us the prospects of social and economic security. This includes; increased food security, poverty eradication, reduced land degradation amongst others (Adekunle et al., 2010). Thus, the onus is on all stakeholders; forest managers, policy makers and the society at large to fraternize to manage our forest in a way that we can use them now and the future generation can still have access to this gift of nature. This way, we will prevent looming danger that eminent from indiscriminate forest clearing.

\begin{tabular}{|c|c|c|c|c|c|}
\hline $\mathbf{S} / \mathbf{N}$ & Species & $\mathrm{S}_{1}\left(\mathrm{~m}^{2}\right)$ & $\mathrm{S}_{\mathrm{m}}\left(\mathrm{m}^{2}\right)$ & $\mathrm{S}_{2}\left(\mathrm{~m}^{2}\right)$ & $\mathbf{V}\left(\mathbf{m}^{3}\right)$ \\
\hline 1 & Albizia lebbeck & 186500.16 & 225901.06 & 306330.64 & 851359.90 \\
\hline 2 & Alstoniaboonei & 31933.44 & 52934.67 & 89593.26 & 203180.78 \\
\hline 3 & Brachystegia nigerica & 170769.06 & 145305.60 & 196931.75 & 578526.85 \\
\hline 4 & Ceiba pentandra & 278424.36 & 387776.99 & 467885.02 & 1400658.77 \\
\hline 5 & Celtis zenkeri & 37477.44 & 55360.17 & 69999.53 & 200530.12 \\
\hline 6 & Chrysophyllum albidum & 23679.04 & 34189.54 & 51573.06 & 129255.59 \\
\hline 7 & Cola gigantean & 32557.39 & 57125.93 & 82460.78 & 209433.84 \\
\hline 8 & Cordiamillenii & 72650.79 & 102508.56 & 152806.50 & 387438.00 \\
\hline 9 & Cucurbita klaineana & 588162.96 & 873193.86 & 1277517.23 & 3266871.78 \\
\hline 10 & Diospyros iturensis & 245415.39 & 332986.50 & 436512.63 & 1227791.86 \\
\hline 11 & Ficus exasperata & 844215.93 & 1168843.74 & 1486269.03 & 4271239.26 \\
\hline 12 & Irvingia gabonensis & 2772657.95 & 4125835.93 & 5278630.22 & 14970140.57 \\
\hline 13 & Mansonia altissima & 6789.80 & 7331.94 & 8570.35 & 27244.73 \\
\hline 14 & Millettia thonningii & 414815.94 & 632756.74 & 767591.44 & 2263957.14 \\
\hline 15 & Nesogordonia papaverifera & 676936.26 & 931179.11 & 1279200.94 & 3463427.10 \\
\hline 16 & Ricinodendron heudelotii & 18018776.71 & 24215571.63 & 30113289.36 & 88398223.62 \\
\hline 17 & Sterculia oblonga & 16913.88 & 42846.25 & 65605.48 & 154797.02 \\
\hline 18 & Terminalia ivorensis & 1878337.01 & 2345804.45 & 2925130.27 & 8649149.00 \\
\hline 19 & Terminalia superba & 84901.80 & 142133.44 & 192768.64 & 515902.49 \\
\hline 20 & Tetracera potatoria & 8116.97 & 9417.47 & 11178.92 & 34730.13 \\
\hline 21 & Triplochiton scleroxylon & 306880.36 & 442105.73 & 565916.80 & 1610263.83 \\
\hline TOTAL & & 26696912.64 & 36331109.29 & 45825761.83 & 132814122.38 \\
\hline
\end{tabular}

Conclusion: The study revealed high volume timber extraction without replacement. The study therefore recommends that for proper planning and managing of Shasha forest reserve, the exploitation rate of the forest should be monitor and forest policy on timber logging and harvesting should be implemented. Regular inventory should be carried out on the exploitation status of the Shasha forest reserve as a yardstick to monitor the exploiting rate of the forest reserve while encouraging community forest management system.

\section{REFERENCES}

Adekunle, V. A. J. (2006). Conservation of tree species diversity in tropical rainforest ecosystem of southwest Nigeria. J of Trop For. Sci. 18 (2): 91101.

Adekunle, V.A.J., Olagoke, A.O and Ogundare, L.F (2010). Rate of timber production in a tropical ecosystem south-western Nigeria and its implications on sustainable forest management, $J$ of For. res, 2(21): 225-230

Boyle, J.R., Tappeiner II, J.C., Waring, R.H. and Tattersall, C (2016): Sustainable forestry: Ecology and silviculture for resilient forests. Elsevier https://doi.org/10.1016.B978-0-12-4095489.09761-X 
Chilalo, M. and Wiersum, K. K. (2011).The Role of Non-Timber Forest Products for Livelihood Diversification in Southwest Ethiopia. Agric and For. issues 3 (1): 44-59

FAO (2000). Forest Resources of Bangladesh: Country Report Rome, 2000. pp. 91

Field Trip Earth (2008).Surveying Wildlife in Nigerian Forest.

Fuwape, J.A. (2001). The impacts of forest industries and wood utilization on the environment. $J$ of Trop for res, 17 (2):78-90

Gamfeldt, L., Snall, T., Bagchi, R., Jonsson, M., Gustafsson, L., Kjellander, P., Ruiz-Jaen, M.C., Froberg, M., Stendahl, J., Philipson, C.D., Mikusinski, G., Andersson, E., Westerlund, B., Andren, H., Moberg, F., Moen, J; Bengtsson, J. 2013. Higher levels of multiple ecosystem services are found in forests with more tree species, Nat comm, 4(1), 1-8

Hush, B., Beers, T.W., and Kershaw, J.A. (2003). Forest mensuration. Wiley.

Iheke, O. R. and Eziuche, A. O. (2016).Forest Resources Exploitation and Its Implications on Rural Agro-Economy in Isiala Ngwa North Local Government Area of Abia State, Nigeria. Nign J of Agric, Food and Environ. 12(1):37-43

Olajide, O., Etigale, E.B. and Udofia, S.I. (2008). Wood-based industries production and sustainable of industrial wood raw materials in Nigeria. In: Onyekwelu, J.C., Adekunle, V.A.J. and Oke, D.O. (eds). Research for development in forestry, forest products natural resource management. The first National Conference of the forest and forest products society held at the Federal University of Technology, Akure, Nigeria, 16th-18th April, 2008.Pp 212-215
Olokeogun, O.S., Iyiola, O.F and Iyiola, K. (2014).Application of Remote Sensing and GIS in land use/land cover mapping and change detection in Shasha forest reserve, Nigeria. The Intl Arch of the Photo Remote Sensing and Spa Info Sci. XL-8613

Ratcliffe, S., Wirth, C., Jucker, T., Plas, F., SchererLorenzen, M., Verheyen, K., Allan, E., Benavides, R., Bruelheide, H., Ohse, B., Paquette, A., Ampoorter, E., Bastias, C.C., Bauhus, J., Bonal, M., Castagneyrol, B., Checko, E., Dawud, S.M., De Wandeler, H., Domisch, T., Finer, L., Fischer, M., Fotelli, M., Gessier, A., Granier, A., Grossiord, C., Guyot, V., Hasse, J., Hattenschwiller, S., Jactel, H., Jaroszewics, B., Joly, F., Kambach, S., Kolb, S., Koricheva, J., Liebersgesell, M.., Milligan, H., Muller, S., Pollastrini, M., Purschke, O., Radoglou, K., Raulund-Rasmussen, K., Roger, F., RuizBenito, P., Seidl, R., Selvi, F., Seiferling, I., Stenlid, J., Valladares, F., Vesterdal, L. Baeten, L. (2017). Biodiversity and ecosystem functioning relations in European forests depends on environmental context. Ecol. Letters 20 (11), 14141426 